\title{
REKONSTRUKSI PROGRAM PERLINDUNGAN DASAR MELALUI PROGRAM PERTANGGUNGAN WAJ IB KECELAKAAN PENUMPANG DAN LALU LINTAS
}

\author{
Mertha Hapsari' ${ }^{1}$, Suteki² \\ Program Studi Magister IImu Hukum \\ Fakultas Hukum Universitas Diponegoro \\ J alan Imam Bardjo, S.H. No. 1-3, Kampus Pleburan, Semarang 50241 \\ merthahapsari@gmail.com
}

\begin{abstract}
The government provides a basic protection for the traffic accident victims through Law No. 33 Year 1964 concerning Passenger Accident Obligatory Insurance Fund in conjunction with Government Regulation No. 17 Year 1965 and Law No. 34 Year 1964 concerning Traffic Accident Obligatory Insurance Fund in conjunction with Government Regulation No. 18 Year 1965. These two laws are made as an initial step to provide social security to people as the road users. However, the provided protection is a third-party legal liability, so not all citizens at street who get traffic accident are covered according to the rules. The problems discussed in this thesis are about the position of Passenger Accident Obligatory Insurance Fund and Traffic Accident Obligatory Insurance Fund in the social security system and how this law provides the protection, which has been regulated and is not yet regulated, to the victims of road traffic accident based on the value of justice. This research used the socio-legal approach methodology with the specifications of descriptive analysis research; the writer attempts to explain the position of an obligatory insurance fund for passenger and traffic accidents in the national social security system and to find the ideal construction for basic protection of the traffic accident victims. The research shows the result that initial purpose of the law to protect all Indonesian people is not yet realized, so it requires reconstruction to implement the basic protection for traffic accident victims based on the value of social justice.
\end{abstract}

\section{Keywords: Basic Protection; Traffic Accident; Reconstruction.}

\begin{abstract}
ABSTRAK
Pemerintah memberikan perlindungan dasar bagi korban kecelakaan lalu lintas melalui Undang-Undang Nomor 33 Tahun 1964 tentang Dana Pertanggungan Wajib Kecelakaan Penumpang jo Peraturan Pemerintah Nomor 17 Tahun 1965 dan Undang-Undang Nomor 34 Tahun 1964 tentang Dana Pertanggungan Wajib Kecelakaan Lalu Lintas Jalan jo Peraturan Pemerintah Nomor 18 Tahun 1965. Kedua Undang-Undang tersebut dibentuk sebagai langkah awal pemberian jaminan sosial kepada masyarakat pengguna lalu lintas. Namun perlindungan yang diberikan bersifat third party liability atau tanggung jawab hukum pihak ketiga, sehingga tidak semua warga Negara yang berada di jalan dan mengalami kecelakaan lalu lintas terjamin menurut Undang-Undang. Permasalahan yang dibahas dalam tesis ini mengenai kedudukan Dana Pertanggungan Wajib Kecelakaan Penumpang dan Dana Pertanggungan Wajib Kecelakaan Lalu Lintas Jalan dalam sistem jaminan sosial dan bagaimana Undang-Undang ini memberikan perlindungan baik yang sudah diatur maupun belum diatur kepada
\end{abstract}

\footnotetext{
1 Mahasiswa Program Studi Magister Ilmu Hukum Universitas Diponegoro
}

2 Dosen Program Studi Magister IImu Hukum Universitas Diponegoro 
korban kecelakaan lalu lintas dengan berbasis nilai keadilan. Dalam penelitian ini menggunakan metode pendekatan Socio-legal dengan spesifikasi penelitian deskriptif analitis, penulis berusaha menjelaskan mengenai kedudukan dana pertanggungan wajib kecelakaan penumpang dan lalu lintas dalam sistem jaminan sosial nasional dan menemukan konstruksi ideal perlindungan dasar bagi korban kecelakaan lalu lintas. Hasil penelitian menunjukkan bahwa tujuan awal dibentuknya Undang-Undang untuk melindungi seluruh masyarakat Indonesia belum terpenuhi, sehingga diperlukan rekonstruksi agar perlindungan dasar kepada korban kecelakaan lalu lintas dapat dilaksanakan berdasar nilai keadilan sosial.

\section{Kata kunci : Perlindungan Dasar; Kecelakaan Lalu Lintas; Rekonstruksi.}

\section{A. PENDAHULUAN}

\section{Latar Belakang}

Tingginya jumlah korban kecelakaan lalu lintas membuat negara merasa perlu untuk memberikan jaminan bagi korban kecelakaan. Pasal 34 ayat (2) UUD NRI 1945 menyatakan, "Negara mengembangkan sistem jaminan sosial bagi seluruh rakyat dan memberdayakan masyarakat yang lemah dan tidak mampu sesuai martabat kemanusiaan." Pasal tersebut menghendaki agar negara mengembangkan sistem jaminan sosial yang mana penyelenggaraannya berada di tangan pemerintahan Negara (Juwana, 2006).

Secara umum ada tiga faktor utama penyebab kecelakaan lalu lintas, yaitu faktor pengguna jalan (road user), faktor kendaraan (vehicle), dan faktor lingkungan jalan (road environment). Kecelakaan yang terjadi pada umumnya tidak hanya disebabkan oleh satu faktor saja, melainkan hasil interaksi antar faktor lain (Asri, 2017).

Sistem jaminan sosial oleh Negara kemudian diwujudkan melalui dibentuknya UU No. 33 Tahun 1964 tentang Dana Pertanggungan Wajib Kecelakaan
Penumpang dan UU No. 34 Tahun 1964 tentang Dana Pertanggungan Wajib Kecelakaan Lalu Lintas Jalan (Nasution, 2016). Sebagai jaminan sosial bagi kecelakaan penumpang dan dana kecelakaan lalu lintas, maka harus dikelola oleh Negara melalui pemerintah sehingga rakyat merasakan kehadiran negara saat menderita kerugian akibat kecelakaan.

Pemerintah membentuk asuransi PT Jasa Raharja (Persero) selaku Badan Usaha Milik Negara (BUMN) berdasarkan Peraturan Pemerintah UndangUndang Nomor 19 Tahun 1960 tentang Perusahaan Negara yang diperbaharui dengan Undang-Undang Nomor 19 Tahun 2003 tentang Badan Usaha Milik Negara (BUMN), yang khusus mengelola asuransi kecelakaan lalu lintas di jalan raya (Dewi, 2017). PT Jasa Raharja (Persero) sebagai pengelola asuransi kecelakaan lalu lintas, menerima iuran dan sumbangan wajib dari pemilik/pengusaha angkutan lalu lintas jalan dan penumpang angkutan umum serta menyalurkannya kembali melalui santunan asuransi kecelakaan lalu lintas jalan (Nasution, 2013). 
Jurnal Pembangunan Hukum Indonesia

Volume 1, Nomor 1, Tahun 2019
Program Studi Magister Ilmu Hukum Fakultas Hukum Universitas Diponegoro
Pelaksanaan asuransi korban kecelakaan lalu lintas pada dasarnya ditujukan kepada setiap orang yang mengalami kecelakaan lalu lintas dalam bentuk korban meninggal dunia, luka-luka, cacat tetap berhak mendapatkan dana santunan kecelakaan ataupun ganti kerugian (Primarta, 2018). Namun perlindungan dasar yang diberikan oleh Undang-Undang No 34 Tahun 1964 bersifat third party liability atau tanggung jawab hukum pihak ketiga. Pasal 4 UU No. 34 Tahun 1964 berbunyi : "Setiap orang yang menjadi korban mati atau cacat tetap akibat kecelakaan yang disebabkan oleh alat angkutan lalu lintas jalan tersebut dalam pasal 1, Dana akan memberi kerugian kepadanya atau kepada ahli warisnya sebesar jumlah yang ditentukan berdasarkan Peraturan Pemerintah".

Dengan demikian, kasus kecelakaan tunggal merupakan kecelakaan yang tidak terjamin oleh Jasa Raharja menurut UU No. 34 Tahun 1964. Pembayaran kecelakaan tunggal selama ini dapat diberikan oleh Jasa Raharja dengan sistem pembayaran ex-gratia, yang merupakan suatu bentuk diskresi dari Direksi Jasa Raharja untuk kasus-kasus di luar jaminan Jasa Raharja.

Jasa Raharja menyadari bahwa korban kecelakaan tunggal perlu untuk mendapatkan perlindungan dari Pemerintah. Ex gratia timbul sebagai suatu upaya untuk memenuhi kebutuhan dalam masyarakat yang belum terakomodir dalam undangundang-undang, sehingga diperlukan adanya suatu hukum baru untuk mengakomodir segala kebutuhan masyarakat. Hukum tidak ada untuk dirinya sendiri, melainkan untuk sesuatu yang lebih luas dan besar. Oleh karena itu, setiap ada masalah dengan hukum, maka hukumlah yang perlu ditinjau dan dperbaiki, bukan manusia yang dipaksa untuk dimasukkan ke dalam skema hukum (Rahardjo, 2009).

Berdasarkan uraian tersebut di atas, dapat dirumuskan permasalahan sebagai berikut:

1) Bagaimana kedudukan Dana Pertanggungan Wajib Kecelakaan Penumpang dan Dana Pertanggungan Wajib Kecelakaan Lalu Lintas Jalan dalam sistem jaminan sosial ?

2) Bagaimana Undang-Undang ini memberikan perlindungan baik yang sudah diatur maupun belum diatur kepada korban kecelakaan lalu lintas dengan berbasis nilai keadilan?

\section{Kerangka Teoritis}

Di dalam penelitian ini digunakan pendekatan socio legal dalam hukum tata negara dengan menggunakan teori politik hukum, teori hukum progresif, dan teori keadilan. Teori tersebut digunakan untuk mendapatkan pemahaman mengenai politik hukum dari perlindungan kepada korban kecelakaan lalu lintas, serta untuk mengetahui bagaimana memberikan perlindungan kepada korban kecelakaan lalu lintas secara adil.

Politik hukum merupakan instrumen pendorong bagi semua unsur sistem hukum nasional, sehingga bertugas sesuai dengan tujuan negara, cita-cita 
Jurnal Pembangunan Hukum Indonesia

Volume 1, Nomor 1, Tahun 2019
Program Studi Magister Ilmu Hukum Fakultas Hukum Universitas Diponegoro bangsa, cita-cita hukum yang terkandung dalam Pembukaan UUD 1945 (Konradus, 2016). Prof Mahfud MD dalam bukunya mengenai Politik Hukum berpendapat bahwa politik hukum merupakan legal policy atau garis (kebijakan) resmi tentang hukum yang akan diberlakukan baik dengan pembuatan hukum baru maupun dengan penggantian hukum lama, dalam rangka mencapai tujuan Negara. Landasan konstitusional yang dijadikan acuan bagi arah politik hukum perlindungan dasar kepada korban kecelakaan lalu lintas adalah Pasal $28 \mathrm{H}$ ayat (3) dan Pasal 34 ayat (2) UUD NRI Tahun 1945. Pasal $28 \mathrm{H}$ ayat (3) menyatakan, "Setiap orang berhak atas jaminan sosial yang memungkinkan pengembangan dirinya secara utuh sebagai manusia yang bermartabat." Pemenuhan akan hak atas jaminan sosial ini menjadi tanggung jawab Negara, sesuai dengan Pasal 34 ayat (2) UUD NRI 1945.

Perlindungan dasar kepada korban kecelakaan lalu lintas ini tujuan utamanya adalah untuk memberikan perlindungan kepada masyarakat Indonesia secara adil. Keadilan dibedakan menjadi keadilan individual dan keadilan sosial. Keadilan individual yaitu suatu keadilan yang pelaksanaannya tergantung pada kehendak pribadi. Sedangkan keadilan sosial adalah keadilan yang pelaksanannya tidak lagi bergantung pada kehendak pribadi, atau pada kebaikan-kebaikan individu yang bersikap adil, tetapi sudah bersifat structural. Artinya, pelaksanaan keadilan sosial sangat tergantung kepada penciptaan struktur-struktur sosial yang adil (Suteki, 2013).

Keadilan menjadi bagian yang tidak terpisahkan dari tujuan hukum itu sendiri, di samping kepastian hukum dan kemanfaatan (Dwisvimiar, 2011). Dalam konsepsi Rawls, keadilan sosial dapat ditegakkan melalui koreksi terhadap pencapaian keadilan dengan cara memperbaiki struktur dasar dari institusi-institusi sosial yang utama, seperti misalnya pengadilan, pasar, dan konstitusi Negara (Faiz, 2009).

Hukum yang baik harus berkompeten dan juga adil, hukum semacam itu seharusnya mampu mengenali keinginan publik dan punya komitmen bagi tercapainya keadilan substantif. Hukum progresif yang dicetuskan oleh Prof Satjipto Rahardjo menegaskan bahwa hukum adalah untuk manusia, dan bukan sebaliknya. "Hukum itu bukan hanya bangunan peraturan, melainkan juga bangunan ide, kultur, dan cita-cita." (Rahardjo, 1991). Prof. Satjipto Raharjo yang menyatakan pemikiran hukum perlu kembali pada filosofis dasarnya, yaitu hukum untuk manusia. Dengan filosofis tersebut, maka manusia menjadi penentu dan titik orientasi hukum.

\section{State of The Art}

Terkait dengan penelitian ini, sebelumnya Fahrul Rozy Nasution telah melakukan penelitian dengan judul "Peran dan Tanggung Jawab PT Jasa Raharja (Persero) dalam Memberikan Santunan Asuransi terhadap Korban Kecelakaan Lalu Lintas Jalan. 
Hasil dari penelitian tersebut menunjukkan PT Jasa Raharja (Persero) sebagai lembaga yang ditunjuk pemerintah dalam melaksanakan pemberian santunan asuransi yang pelaksanaannya diatur dalam UndangUndang Nomor 34 Tahun 1964 serta asuransi kecelakaan lalu lintas tidak hanya diberikan kepada korban kecelakaan lalu lintas antara kendaraan bermotor saja, namun juga diberikan kepada pejalan kaki yang ditabrak oleh kendaraan bermotor.

\section{Permasalahan dan GapAnalysis}

Penelitian ini perlu dilakukan untuk menelaah tentang rekonstruksi UU No. 33 Tahun 1964 dan UU No. 34 Tahun 1964. Penelitian yang sebelumnya dilakukan hanya menekankan pada peran Jasa Raharja dan perlindungan terhadap korban kecelakaan Ialu lintas, namun belum menalaah mengenai rekonstruksi perlindungan dasar bagi korban kecelakaan lalu lintas.

Penelitian ini dilakukan bertujuan untuk mengetahui kedudukan Dana Pertanggungan Wajib Kecelakaan Penumpang dan Lalu Lintas Jalan dalam Sistem Jaminan Sosial, serta untuk mengetahui bagaimana program perlindungan memberi rasa keadilan bagi korban kecelakaan lalu lintas.

\section{B. METODE PENELITIAN}

Penelitian hukum pada dasarnya merupakan suatu kegiatan ilmiah yang didasarkan pada metode, sistematis dan pemikiran tertentu yang bertujuan untuk mempelajari satu atau beberapa gejala hukum tertentu dengan jalan menganalisanya, kecuali itu maka juga diadakan pemeriksaan yang mendalam terhadap fakta hukum tersebut untuk kemudian ditimbulkan dalam gejala yang bersangkutan.

Menurut Bogdan dan Biklen sebagaimana dikutip Soerjono Soekanto dalam bukunya (Soekanto, 2004), analisis data adalah proses pencarian dan penyusunan data yang sistematis melalui transkrip wawancara, catatan lapangan, dan dokumentasi yang secara akumulasi menambah pemahaman peneliti yang ditemukan. Data primer dan data sekunder tersebut dikumpulkan dan disusun secara sistematis, jelas dan teratur dalam penulisan ini, kemudian data tersebut dianalisa menurut disiplin ilmu hukum tata negara sehingga menjadi data pembahasan sinergis dan terpadu.

Metode pendekatan yang digunakan dalam penelitian ini menggunakan pendekatan Socio-legal. Jenis data yang digunakan adalah data primer yang diperoleh dan data sekunder. Data primer diperoleh dengan mengamati secara langsung fenomena atau gejala sosial yang diteliti, dalam hal ini data diperoleh dari wawancara dengan PT Jasa Raharja (Persero). Data sekunder diperoleh dari data kepustakaan yang di dalamnya mengandung bahan hukum yang meliputi bahan hukum primer, bahan hukum sekunder, dan bahan hukum tersier dengan metode pengumpulan data yang dipakai adalah studi kepustakaan. 


\section{HASIL PENELITIAN DAN PEMBAHASAN}

1. Kedudukan Dana Pertanggungan Wajib Kecelakaan Penumpang dan Lalu Lintas Jalan dalam Sistem J aminan Sosial

a. Kewajiban Negara dalam Melaksanakan Dana Pertanggungan Wajib Kecelakaan Penumpang dan Dana Pertanggungan Wajib Kecelakaan Lalu Lintas J alan

Pembukaan UUD 1945 menjelaskan mengenai tujuan dari pembentukan Pemerintahan Negara Indonesia yaitu untuk melindungi segenap bangsa Indonesia dan seluruh tumpah darah Indonesia dan memajukan kesejahteraan umum.

Terkait dengan perlindungan kesehatan, terutama yang berkaitan dengan kecelakaan penumpang dan kecelakaan lalu lintas jalan, negara memiliki peran dalam penyediaan pelayanan kesehatan. Peran negara untuk melindungi kecelakaan yang menimpa warganya menjadi sebuah kewajiban konstitusional tersendiri.

\section{b. Politik Hukum Dana Pertanggungan Wajib}

Berdasarkan UU No. 33 dan UU No. 34 Tahun 1964 Dimaksudkan sebagai Bagian dari Sistem J aminan Sosial

Menurut Satjipto Rahardjo, politik hukum adalah sebagai aktivitas memilih dan cara yang hendak dipakai untuk mencapai suatu tujuan sosial dan hukum tertentu dalam masyarakat. Prof Mahfud MD menambahkan bahwa politik hukum paling tidak mempunyai dua sifat yakni permanen dan periodik
(Mahfud MD, 2012). Politik hukum mengatur prinsip double movement, yaitu selain sebagai kerangka pikir merumuskan kebijakan dalam bidang hukum (legal policy) oleh lembaga-lembaga Negara yang berwenang, ia juga dipakai untuk mengkritisi produkproduk hukum yang telah diundangkan berdasarkan legal policy di atas.

Secara umum politik hukum terkait dengan hukum, yaitu hukum seperti apa yang akan digunakan untuk mengatur kehidupan bermasyarakat, berbangsa, dan bernegara. Politik hukum tersebut harus sesuai dengan nillai-nilai maupun pandangan hidup dari bangsa yang bersangkutan (Putri, 2015).

Teori perjenjangan hukum menurut Hans Kelsen (Sudut hukum, 2017) berpendapat bahwa normanorma hukum berjenjang-jenjang dan berlapis-lapis dalam suatu hierarki tata susunan, dimana suatu norma yang lebih rendah berlaku, bersumber, dan berdasar pada norma yang lebih tinggi, norma yang lebih tinggi berlaku, bersumber dan berdasar pada norma yang lebih tinggi lagi, demikian seterusnya sampai pada norma yang tidak dapat ditelusuri lebih lanjut dan bersifat hipotesis dan fiktif, yaitu norma dasar (grundnorm). Hans Nawiansky mengembangkan teori dari Hans Kelsen. Menurut Hans Nawiasky (Nawiansky, 2010) suatu norma hokum dari Negara manapun selalu berlapis-lapis dan berjenjang-jenjang. Norma yang di bawah berlaku bersumber dan berdasar pasa suatu norma tertinggi yang disebut norma dasar. 
Jurnal Pembangunan Hukum Indonesia

Volume 1, Nomor 1, Tahun 2019
Program Studi Magister Ilmu Hukum Fakultas Hukum Universitas Diponegoro
Penjelasan politik hukum perlindungan korban kecelakaan melalui penyaluran dana pertanggungan wajib kecelakaan penumpang dan lalu lintas jalan apabila dikaitkan dengan teori perjenjangan hukum milik Hans Kelsen dapat ditarik kesimpulan sebagai berikut :

a. Pancasila, sebagai dasar Negara merupakan pedoman, norma dasar, cita hukum dalam setiap penyelenggaraan Negara termasuk dalam perlindungan kepada korban kecelakaan lalu lintas. Sehingga sila ke 5 Pancasila yang berbunyi "Keadilan Sosial bagi Seluruh Rakyat Indonesia" dijadikan landasan dalam perlindungan dasar kepada korban kecelakaan lalu lintas.

b. UUD NRI 1945, merupakan landasan konstitusional atau peraturan hukum tertinggi di Indonesia. Terkait tentang perlindungan dasar kepada korban kecelakaan lalu lintas, maka dalam setiap penyusunan perundang-undangan selalu menempatkan Pasal 34 ayat (2) dan Pasal $28 \mathrm{H}$ ayat (3) UUD NRI Tahun 1945 sebagai politik hukum di tataran konstitusional.

C. Undang-Undang Nomor 33 Tahun 1964 tentang Dana Pertanggungan Wajib Kecelakaan Penumpang dan Undang-Undang Nomor 34 Tahun 1964 tentang Dana Pertanggungan Wajib Kecelakaan Lalu Lintas Jalan merupakan peraturan perundang-undangan yang utama pada tataran instrumental yang mengatur secara teknis perlindungan dasar korban kecelakaan lalu lintas. d. Politik hukum perlindungan dasar korban kecelakaan lalu lintas pada tataran implementasi, sampai dengan saat ini masih terdapat gap antara peraturan perundang-undangan dengan kondisi yang ada di masyarakat. Ruang lingkup pertanggungan menurut Undang-Undang yang memberi batasan bahwa yang mendapatkan perlindungan adalah pihak ketigs yang berada dilusr kendaraan penyebab menyebabkan korban kecelakaan tunggal tidak medapat perlindungan oleh Negara. Permasalahan tersebut didasari oleh Jasa Raharja sebagai pelaksana Undang-Undang tersebut dan muncul kebijakan pemberian diskresi akibat tingginya angka kecelakaan yang tidak terjamin oleh Negara.

\section{Asuransi Kecelakaan Transportasi di Mancanegara}

Asuransi tanggung gugat pihak ketiga yang bersifat wajib dilaksanakan berdasarkan Road trafict Act 1930 yang disempurnakan dengan Road Trafict Act 1974. Konsep asuransi ini berlaku secara universal di dunia dan menjadi bagian dari Compulsory Motor Insurance di berbagai negara. (Nasution, 2016). Menurut Juwana (2016: 15-20) berikut merupakan penyelenggaraan asuransi kecelakaan transportasi di beberapa negara di dunia:

a. Thailand menerapkan Proteksi berupa Third Party Liability termasuk body injuries.

b. Malaysia menerapkan Compulsory Third Party Insurance dan Public Passenger Liability Insurance. 
c. Laos menerapkan proteksi meliputi Third Party Liability dalam hal bodily injury, manfaat perawatan dan property (Comparison of Compulsory Automobile Liability Insurance atau CALI dan pertemuan regional pelaksana asuransi wajib di ASEAN).

d. Spanyol menerapkan proteksi Compulsory Motor Vehicle Insurance dalam bentuk third party liability untuk bodily injuries (ref : http://ec.europa.eu/internal_market/insurance/docs/ guarantee/panel/machetti_en.pdf).

Pada prinsipnya asuransi wajib bertujuan untuk setidak-tidaknya memberikan perlindungan kepada pihak ketiga atas penggunaan kendaraan bermotor dari pemilik/pengendara kendaraan bermotor, yang pembayaran premi dibebankan kepada pemilik/pengendara kendaraan bermotor.

Ruang lingkup dari asuransi kecelakaan di Indonesia ini dikhususkan untuk kecelakaan lalu lintas dari kendaraan bermotor, yaitu tabrakan antara kendaraan bermotor atau apabila penyebab dari kecelakaan adalah kendaraan bermotor, seperti yang terdapat di dalam Pasal 4 ayat (1) UU No. 34 Tahun 1964. Berdasarkan ketentuan tersebut pemerintah memberikan perlindungan dasar kepada masyarakat yang menjadi korban diluar kendaraan yang menjadi penyebab timbulnya kecelakaan. Dengan demikian, setiap orang yang menjadi korban kecelakaan tersebut merupakan pihak ketiga yang mendapat jaminan sesuai UU Nomor 34 Tahun 1964, sehingga kasus kecelakaan tunggal tidak terjamin menurut UndangUndang.

Walaupun konsep asuransi dengan proteksi third party liability pada UU No 34 Tahun 1964 telah sejalan dengan best practice dan kaedah umum yang berlaku di dunia perasuransian, namun kita kembali lagi melihat pada ideologi kita, yakni sila ke- 5 Pancasila, "Keadilan Sosial bagi Seluruh Rakyat Indonesia" konsep tersebut belum memberikan keadilan secara merata pada korban kecelakaan lalu lintas di Indonesia.

\section{Deskripsi Kasus Belum Tercapainya Nilai Keadilan dalam Program Perlindungan Dasar Melalui Penyaluran Dana Pertanggungan Wajib Kecelakaan Penumpang dan Lalu Lintas J alan}

Konsep third party liability atau tanggung jawab hukum pihak ketiga diadopsi oleh UU Nomor 34 Tahun 1964 dan menjadi acuan Jasa Raharja dalam menjalankan tugas serta fungsinya sebagaimana tertuang dalam naskah perumusan UU Nomor 34 Tahun 1964 (Memori Van Toelechting). Mekanisme perlindungan adalah proteksi dasar dan pihak yang diwajibkan untuk melakukan pembayaran Sumbangan Wajib Dana Kecelakaan Lalu Lintas (SWDKLLJ, sejumlah uang yang dibayarkan kepada Jasa Raharja saat pemilik kendaraan bermotor melakukan pengesahan/pembayaran Pajak Kendaraan Bermotor tiap tahunnya) adalah pemilik kendaraan bermotor.

Ruang lingkup pertanggungan sebagaimana dimaksud dalam Pasal 4 ayat (1) UU No. 34 Tahun 
Jurnal Pembangunan Hukum Indonesia

Volume 1, Nomor 1, Tahun 2019

1964 adalah kepada korban yang berada di luar kendaraan penyebab. Lebih lanjut, dalam penjelasan pasal 4 ayat (1) UU Nomor 34 Tahun 1964, menyatakan:

"Yang mendapatkan jaminan berdasarkan undangundang ini ialah mereka yang berada dijalan diluar alat angkutan yang menyebabkan kecelakaan. Namun demikian, bila si korban ini telah dapat jaminan berdasarkan Undang-Undang tentang Dana Pertanggungan Wajib Kecelakaan Penumpang Nomor 33 Tahun 1964, maka jaminan hanya diberikan satu kali, yaitu oleh Dana Pertanggungan Wajib Kecelakaan Penumpang yang dimaksud dalam Undang-Undang tersebut".

Hal tersebut ditegaskan kembali dalam Peraturan Pemerintah Nomor 18 Tahun 1965 yang merupakan peraturan pelaksana dari UU Nomor 34 Tahun 1964 melalui Pasal 10 ayat (1), berbunyi sebagai berikut :

"Setiap orang yang berada diluar alat angkutan lalu lintas jalan yang menimbulkan kecelakaan, yang menjadi korban akibat kecelakaan dari penggunaan alat angkutan lalu lintas jalan tersebut sebagai demikian diberi hak atas suatu pembayaraan dari Dana Kecelakaan Lalu Lintas J alan, kecuali hal-hal yang tercantum dalam Pasal 13."

Dapat disimpulkan bahwa:

a. Ruang lingkup jaminan sebagaimana dimaksud dalam UU Nomor 34 Tahun 1964 Jo. PP Nomor 18 Tahun 1965 adalah setiap orang yang menjadi korban akibat kecelakaan yang disebabkan oleh alat angkutan yang menjadi penyebab kecelakaan.

b. UU Nomor 34 Tahun 1964 menjamin setiap korban di luar alat angkutan yang menimbulkan kecelakaan, dengan demikian korban yang berada
Program Studi Magister Ilmu Hukum Fakultas Hukum Universitas Diponegoro di dalam alat angkutan yang menjadi penyebab kecelakaan tidak terjamin oleh undang-undang.

Hal tersebut yang menjadi dasar bahwa kecelakaan tunggal tidak terjamin oleh UndangUndang. Namun, tingginya angka kecelakaan di masyarakat saat ini menyebabkan aturan tersebut tidak sesuai dengan kondisi yang ada.

Jasa Raharja menerapkan suatu bentuk diskresi berupa Ex-G ratia yang dituangkan dalam Surat Edaran Kantor Pusat Nomor P/SE/117/XII/1981 tanggal 31 Desember 1981 tentang Penyelesaian Pembayaran Santunan Dana Melalui Jalur "Ex Gratia et sans projudice" oleh Cabang-Cabang.

Dalam ketentuan tersebut dijelaskan bahwa Direksi memberikan wewenangnya dalam batas-batas tertentu setelah menerima permohonan tertulis dari korban atau ahli waris korban dan mempelajari permasalahan dengan sebaik-baiknya. Pembayaran Ex-Gratia dilakukan dengan pertimbangan yaitu : korban adalah kepala keluarga sehingga dengan meninggalnya atau lukanya korban akan berpengaruh pada perekonomian keluarga yang ditinggalkan.

Dalam pelaksanaannya, kebijakan tersebut didelegasikan kepada Kepala Cabang dengan ketentuan yang diatur Perusahaan. Kebijakan tersebut ada untuk menjembatani gap yang terjadi antara peraturan perundang-undangan dengan kondisi yang ada di masyarakat. Hal tersebut menunjukkan bahwa negara menyadari perlunya perlindungan dasar kepada seluruh korban kecelakaan lalu lintas, termasuk korban 
Jurnal Pembangunan Hukum Indonesia

Volume 1, Nomor 1, Tahun 2019

kecelakaan tunggal yang tidak terjamin oleh UndangUndang.

\section{Kontruksi Ideal Perlindungan Dasar terhadap} Korban Kecelakaan Lalu Lintas

\section{a. Pendekatan Hukum Progresif dalam Perlindungan Dasar terhadap Korban Kecelakaan Lalu Lintas}

Hukum progresif melihat dunia dan hukum dengan pandangan yang mengalir, seperti Panta Rei (semua mengalir) dari filsuf Heraklitos. Paradigma dalam hukum progresif adalah bahwa "hukum adalah untuk manusia". Upaya pembangunan tata hukum terus menerus diperlukan agar hukum dapat memainkan peran dan fungsinya sebagai pedoman bertingkah laku dalam hidup bersama. Hukum harus disesuaikan dengan perkembangan masyarakat yang dilayaninya dan hukum berfungsi sebagai alat pendorong kemajuan masyarakat.

Dalam hukum progresif juga selalu melekat etika dan moralitas kemanusiaan, yang akan memberikan respon terhadap perkembangan dan kebutuhan manusia serta mengabdi pada keadilan, kesejahteraan, kemakmuran dan kepedulian terhadap manusia pada umumnya (Paturusi, 2013). Adagium bahwa hukum adalah untuk manusia perlu dipertahankan dari berbagai bentuk falsiable agar kedudukan hukum sebagai alat (tool) untuk mencapai sesuatu, bukan sebagai tujuan yang sudah final (Ravena, 2010).
Program Studi Magister Ilmu Hukum Fakultas Hukum Universitas Diponegoro
Law as a process, law in the making, menunjukkan bahwa hukum akan tampak selalu bergerak, berubah, mengikuti dinamika kehidupan manusia. Akibatnya hal ini akan mempengaruhi pada cara pelaksanaan hukum kita, yang tidak akan sekedar terjebak dalam ritme "kepastian hukum", status quo dan hukum sebagai skema yang final, melainkan suatu kehidupan hukum yang selalu mengalir baik itu melalui perubahan undang-undang maupun pada kultur hukumnya (Mukhidin, 2015).

Pembaharuan tatanan hukum pada perlindungan bagi korban kecelakaan lalu lintas harus memiliki konsistensi arah politik hukum baik secara vertikal maupun horizontal, secara vertikal artinya arah politik hukum yang ada dalam Pancasila dan UUD NRI Tahun 1945 harus menjadi pedoman bagi arah politik ukum dalam undang-undang dengan kata lain politik hukum secara ideal (yang ada dalam pembukaan UUD NRI Tahun 1945) akan menjadi pijakan bagi politik hukum secara dasar (UUD NRI Tahun 1945), dan politik hukum secara dasar menjadi pijakan bagi politik hukum secara instrumental (Undang-Undang). Sementara secara horizontal arah politik hukum yang ada dalam undang-undang yang satu harus konsisten dengan arah politik hukum dalam undang-undang yang lain.

Tujuan awal dibentuknya Undang-Undang Nomor 33 dan 34 Tahun 1964 adalah untuk memberi perlindungan kepada seluruh masyarakat Indonesia. Namun pada saat itu hal tersebut belum dapat 
Jurnal Pembangunan Hukum Indonesia

Volume 1, Nomor 1, Tahun 2019

dilakukan dikarenakan kondisi keuangan negara yang tidak memungkinkan. Seiring berjalannya waktu, dengan tingkat kecelakaan yang semakin tinggi sudah seharusnya Undang-Undang tersebut dikaji kembali.

\section{b. Rekonstruksi Perlindungan Dasar terhadap Korban Kecelakaan Lalu Lintas Melalui Dana Pertanggungan Wajib Kecelakaan Penumpang dan Lalu Lintas Jalan Berbasis Nilai Keadilan Sosial}

Frasa "di luar" dalam Pasal 4 ayat (1) UndangUndang Nomor 34 Tahun 1964 belum lama ini diuji materiil oleh Mahkamah Konstitusi. Dalam Putusan Mahkamah Konstitusi Nomor 88/PUU-XV/2017 Majelis Hakim menolak permohonan pemohon untuk seluruhnya. Majelis Hakim berpendapat bahwa jaminan sosial yang diatur dalam UU No. 34 Tahun 1964 memang hanya dimaksudkan dan dibatasi untuk kecelakaan terhadap mereka yang berada di jalan di luar alat angkutan dan tidak tercakup kecelakaan tunggal. Namun dalam pertimbangannya majelis hakim berpendapat sebagai berikut:

"[3.14.3]...Lebih jauh, sepanjang santunan ex-gratia tidak diposisikan dan tidak dimaksudkan sebagai bagian dari jaminan kecelakaan sesuai UndangUndang a quo, maka diskresi itu sama sekali tidak keluar dari apa yang diatur Undang-Undang dimaksud".

"[3.14.4]... Perihal belum adanya pengaturan dalam bentuk undang-undang (rechtsvacuum) tentang santunan bagi mereka yang mengalami kecelakaan tunggal, hal itu tidaklah berarti Undang-Undang a quo tidak konstitusional, sebab memang bukan demikian maksud dibentuknya undang-undang ini.
Program Studi Magister Ilmu Hukum Fakultas Hukum Universitas Diponegoro

Dengan kata lain, perlunya ada pengaturan perihal pemberian santunan bagi mereka yang mengalami kecelakaan tunggal harus dipertimbangkan sebagai bagian dari ius constituendum untuk masa yang akan datang karena adanya tuntutan kebutuhan untuk itu, bukan dengan menyalahkan undangundang a quo".

Berdasarkan pertimbangan hakim di atas, dapat kita simpulkan bahwa Ex-gratia merupakan diskresi yang dapat dibenarkan dikarenakan sejalan dengan tujuan awal undang-undang untuk memberikan perlindungan dasar kepada korban kecelakaan lalu lintas. Namun hal tersebut hanya dapat dijadikan sebagai kebijakan, dan bukan bagian dari ruang lingkup jaminan kecelakaan sebagaimana diatur dalam peraturan perundang-undangan. Ex-gratia timbul sebagai suatu upaya untuk memenuhi kebutuhan dalam masyarakat yang belum terakomodir dalam undang-undang, sehingga diperlukan suatu hukum baru (ius constituendum) untuk mengakomodir segala kebutuhan masyarakat.

Arah politik hukum dalam Undang-Undang Nomor 34 Tahun 1964 tentang Dana Pertanggungan Wajib Kecelakaan Lalu Lintas Jalan ke depan harus dilakukan perubahan agar sesuai dengan kondisi dan kebutuhan masyarakat saat ini, antara lain: Pertama, ruang lingkup pertanggungan menurut Undang-Undang ini, selama ini diberikan batasan bahwa yang terjamin menurut Undang-Undang hanyalah korban yang menjadi korban yang berada di luar alat angkutan penumpang, sehingga korban kecelakaan seperti 
Jurnal Pembangunan Hukum Indonesia

Volume 1, Nomor 1, Tahun 2019
Program Studi Magister Ilmu Hukum Fakultas Hukum Universitas Diponegoro kecelakaan tunggal tidak termasuk dalam lingkup jaminan. Untuk melakukan rekonstruksi perlindungan dasar terhadap korban kecelakaan lalu lintas, penulis menggunakan teori hukum progresif sebagai pisau analisis.

Perspektif hukum progresif dinilai sebagai suatu strategi yang paling tepat untuk menembus legalitas formal dan menggali lebih dalam keadilan yang ada di masyarakat. Rekonstruksi harus diawali dengan pembebasan dari politik hukum existing menuju politik hukum yang ideal dengan cara mengarahkan hukum pada tujuan yang sebenarnya yaitu hukum yang membahagiakan dan mensejahterakan manusia.

Dr. Firdaus Jaelani, dalam Focus Group Discussion yang diadakan oleh Jasa Raharja pada 13 Juli 2018 berpendapat bahwa untuk memperluas jaminan bagi korban kecelakaan lalu lintas yang tidak terjamin oleh Undang-Undang jalan satu-satunya adalah melalui amandemen Undang-Undang.

Jasa Raharja dalam bentuknya sebagai Persroan Terbatas memiliki sejumlah kelemahan. Pertama, dana yang dikelola Jasa Raharja bisa menjadi dividen dan tidak dikembalikan sebagai dana sebagaimana diatur dalam UU No. 33 dan 34 Tahun 1964. Sehingga, Jasa Raharja secara hukum tidak berprinsip nirlaba, sebagaimana prinsip kedua dalam Sistem Jaminan Sosial Nasional. Walaupun Jasa Raharja memiliki karakteristik asuransi sosial, tetapi sebagai Perseroan Terbatas, Jasa Raharja mempunyai orientasi untuk mendapatkan profit meskipun tetap dalam rambu-rambu asuransi sosial. Dr. Firdaus Djaelani juga sependapat dalam hal tersebut, beliau berpendapat bahwa sesuai dengan tujuan awal pembentukan UU No. 34 Tahun 1964 serta semangat dalam memberikan pelayanan, untuk memperluas jaminan perlindungan, idealnya Jasa Raharja harus berubah status dari Perseroan Terbatas menjadi Badan layaknya BPJS. Oleh karena itu lebih baik agar bentuk perusahaan penyelenggara perlindungan korban kecelakaan lalu lintas dirubah berbentuk Badan Penyelenggara Jaminan Sosial di bidang kecelakaan.

\section{PENUTUP}

\section{Kesimpulan}

Dana Pertanggungan Wajib Kecelakaan Penumpang dan Lalu Lintas Jalan merupakan bagian dari Sistem Jaminan Sosial Nasional di Indonesia. UU No.33 dan 34 Tahun 1964 sebagai hokum di Indonesia dibentuk dengan pertimbangan sebagai langkah awal menuju terbentuknya sistem jaminan sosial di Indoensia.

Ruang lingkup pertanggungan kecelakaan yang selama ini diatur oleh UU No. 34 Tahun 1964 terbatas hanya kepada pihak ketiga yang berada di luar kendaraan penyebab. Padahal angka kecelakaan saat ini semakin lama semakin meningkat, dan banyak kecelakaan tunggal yang terjadi namun tidak termasuk di dalam ruang lingkup jaminan.

Adanya diskresi pemberian ex gratia terhadap korban kecelakaan menunjukkan bahwa negara 
Jurnal Pembangunan Hukum Indonesia

Volume 1, Nomor 1, Tahun 2019
Program Studi Magister Ilmu Hukum Fakultas Hukum Universitas Diponegoro sebenarnya menyadari adanya kebutuhan di dalam masyarakat. Namun selama ini hanya dapat diberikan melalui kebijakan karena batasan yang dimiliki oleh Undang-Undang Nomor 34 Tahun 1964 maupun Peraturan Pelaksana Nomor 18 Tahun 1965.

Majelis Hakim Mahkamah Konstitusi dalam pertimbangannya atas uji materiil terhadap UU No. 34 Tahun 1964 juga berpendapat bahwa terkait kecelakaan tunggal yang selama ini dibayarkan melalui diskresi patut menjadi pertimbangan untuk disusunnya suatu hukum baru (ius constituendum). Berdasarkan pertimbangan - pertimbangan di atas, rekonstruksi terhadap program perlindungan dasar terhadap korban kecelakaan lalu lintas perlu segera dilaksanakan sehingga sesuai dengan kondisi di masyarakat saat ini dan dapat memberikan rasa keadilan kepada seluruh korban kecelakaan lalu lintas.

\section{DAFTAR PUSTAKA}

\section{Buku:}

Juwana, H. (2016). Jaminan Sosial Kecelakaan sebagai Wujud Kehadiran Negara. Jakarta: Spora Consultant.

Nasution, B. (2016). J aminan Sosial Kecelakaan dalam Perspektif UU No. 40 Tahun 2014 tentang Perasuransian. Jakarta: Spora Consultant.
Rahardjo, S. (2009). Hukum Progresif : Sebuah Sintesa Hukum Indonesia. Yogyakarta: Genta Publishing.

Soekanto, S. (2004). Pengantar Metode Penelitian Hukum. Jakarta: Grafindo Persada.

Suteki. (2013) . Desain Hukum di Ruang Sosial. Yogyakarta: Thafa Media.

Mahfud MD, M. (2009). Politik Hukum di Indonesia. Jakarta: PT Raja Grafindo Persada.

\section{J urnal}

Asri, K. (2017). Pelaksanaan Asuransi Sosial pada PT Jasa Raharja (Persero) terhadap Korban Kecelakaan Lalu Lintas di Kota Semarang. Diponegoro Law J ournal, Vol. 6 (No.2), p 3.

Dewi, R. (2017). Perlindungan Hukum terhadap Korban/Ahli Waris Akibat Kecelakaan Lalu Lintas Jalan. Syiah Kuala Law J ournal, Vol 1 (No. 2), p. 124.

Dwisvimiar, I.(2011). Keadilan dalam Perspektif Filsafat IImu Hukum. Jurnal Dinamika Hukum, Vol.11 (No.3), p.524.

Faiz, M. (2009). Teori Keadilan Jhon Rawls. Jurnal Konstitusi, Vol.6, (No. 1), p. 136.

Konradus, D. (2016). Politik Hukum berdasarkan Konstitusi. Jurnal Masalah-Masalah Hukum, Vol.45, (No.3), p. 205. 
Jurnal Pembangunan Hukum Indonesia

Volume 1, Nomor 1, Tahun 2019

Mukhidin. (2015). Hukum Progresif sebagai Solusi Hukum yang Mensejahterakan Rakyat. J urnal Pembaharuan Hukum, Vol.I (No. 3), p. 267.

Primarta, C. (2018). Analisis Undang-Undang Nomor 40 Tahun 2014 tentang Perasuransian terhadap Jaminan Sosial Korban Kecelakaan Lalu Lintas di PT Jasa Raharja (Persero) Cabang Jawa Tengah. Jurnal Daulat Hukum, Vol. 1 (No.1), p 217.

Putri, R. (2015). Kajian Politik Hukum tentang Perubahan Kewenangan Pemberian Izin Usaha Pertambangan Mineral dan Batubara. Jurnal Law Reform, Vol 11 (No. 2), p. 201.

Ravena, D. (2010). Wacana Konsep Hukum Progresif dalam Penegakan Hukum di Indonesia. Jurnal Wawasan Hukum, Vol. 23 (No.2), p. 156.

Nasution, Fahrul R. (2013). Peran dan Tanggung Jawab PT Jasa Raharja (Persero) dalam Memberikan Santunan Asuransi terhadap Korban Kecelakaan Lalu Lintas Jalan (Studi pada PT Jasa Raharja (Persero) Cabang Rantauprapat). J urnal Civil Law Vol 2, p.3.

\section{Website}

Sudut Hukum. (2017). Teori Penjenjangan Norma Hukum. Retrieved from www.suduthukum.com, diakses pada tanggal 1 Agustus 2018

Paturusi, Ahmad T. (2013). Paradigma Hukum Progresif Konsep Prorograsi. Retrieved from
Program Studi Magister Ilmu Hukum Fakultas Hukum Universitas Diponegoro

www.negarahukum.com, diakses pada 27 November 2018 